\title{
Fad Diets: Lifestyle Promises and Health Challenges
}

\author{
Jomana Khawandanah $^{1} \&$ Ihab Tewfik $^{1}$ \\ ${ }^{1}$ Department of Life Sciences, Faculty of Science and Technology, University of Westminster, London, UK \\ Correspondence: Jomana Khawandanah, Department of Life Sciences, Faculty of Science and Technology, \\ University of Westminster, 115 New Cavendish Street, London W1W 6UW, United Kingdom. E-mail: \\ j_khawandanah@hotmail.com
}

Received: September 12, 2016

Accepted: October 12, $2016 \quad$ Online Published: November 16, 2016

doi:10.5539/jfr.v5n6p80

URL: http://dx.doi.org/10.5539/jfr.v5n6p80

\begin{abstract}
Chronic excess of dietary intake combined with reduced energy expenditure increase the positive energy balance. This transition in behaviour contributes significantly to prevalence of obesity, impairment of health, reduction in quality of life and increases health-care costs. While obesity has turned into a public health threat, with the government failing to reverse this growing trend, good number of people is undertaking fad diets with the hope to lose weight fast and easy. Furthermore, media and peers contribute to the popularity of fad diets as they put pressure to individuals who desire a certain body image, which leads to low self-esteem and perhaps eating disorders. Despite the fact that fad diets may appeal as simple way to lose weight, recent studies have shown that such diets in the long term are unsustainable and can bring adverse side effects to health. Consideration of the reviewed literature suggests that long-life changes in diet and lifestyle might be the best approaches to maintain a healthy weight in the long term. Overweight individuals should consult nutrition professions before adopting any fad diets to minimise the health risks and psychological impacts.
\end{abstract}

Keywords: Atkins diet, dieting, eating disorder, fad diets, obesity, overweight, public health, weight loss, yo-yo dieting

\section{Introduction}

\subsection{The Epidemic of Obesity}

Since 1980 the number of people suffering from obesity has doubled on a worldwide level. According to the latest figures published by World Health Organisation (WHO) (2015) almost 2 billion adults (39\%) were overweight (Body Mass Index, BMI $\left.\geq 25 \mathrm{~kg} / \mathrm{m}^{2}\right)$, with 600 million of these $(13 \%)$ being obese $\left(\mathrm{BMI} \geq 30 \mathrm{~kg} / \mathrm{m}^{2}\right)$. Both being overweight and obese is characterised by excess fat mass in the body (WHO, 2015). The main factors causing obesity involve excessive calorie intake, unhealthy eating habits like consuming processed food, sedentary lifestyle, but also medical conditions (hypothyroidism) or genetics such as the Prader-Willi syndrome (National Health Services [NHS], 2014a).

There is plenty of evidence showing that obesity is one of the major public health threats also to the UK; according to NHS statistics in 2011, 65\% of men and 58\% of women over 16 years old are overweight or obese (Health and Social Care Information Centre [HSCIC], 2013). These figures pose a threat to the society, which can be translated into non-communicable diseases, morbidity and mortality if not treated, with a high economic burden to NHS.

There is no doubt that obesity can lead to various health problems. Common public health consequences associated with abnormal fat deposits include cardiovascular diseases, especially heart attack and stroke, diabetes, cancer as well as musculoskeletal disorders, mainly osteoarthritis (Weight-control Information Network [WIN], 2014; WHO, 2015). On the other hand, the mechanical stress induced by obesity can result in disabilities caused by several conditions such as shortness of breath, sleep apnoea, osteoarthritis and low back pain (Visscher \& Seidell, 2001).

Given the current trend it seems like government actions to tackle obesity are failing. No country has managed to show any supporting evidence for improvements. Policymakers do not seem to be working quickly to identify those reasons and yet they expect fast outcomes. Intervention plans based on a broader approach that deals with agriculture, product manufacture and education might be a starting point to reverse those trends. Table 1 below shows the complexity of factors that contribute to obesity interventions failure. 


\subsection{Health Practices: Healthy Eating and Physical Activity}

There is no doubt that adjusting the daily nutritional intake and eating habits can have a major impact on weight management. In order to lose weight, the daily energy expenditure has to be greater than the consumed energy intake; therefore reducing the daily calories can help towards this goal. Healthy eating together with being physically active should be the right choice for obese individuals if they want to achieve long-term weight loss (NHS, 2014b). However, current lifestyles and easy access to cheap junk food has resulted in unhealthy eating behaviours and a routine with minimal physical activity (NHS, 2013).

Table 1. Failure and factors shaping obesity in developed countries (Source: Lang \& Rayner, 2007)

\begin{tabular}{|c|c|c|c|c|c|}
\hline \multirow{3}{*}{$\begin{array}{l}\text { Focus of } \\
\text { failure }\end{array}$} & \multicolumn{5}{|l|}{ Factors shaping obesity } \\
\hline & \multicolumn{2}{|l|}{ Domains } & \multicolumn{3}{|l|}{ Transitions } \\
\hline & Body & Mind & Diet & Physical activity & Culture \\
\hline Markets & $\begin{array}{l}\text { - Highlight and over- supply } \\
\text { particular taste receptors } \\
\text { (sweet and fat) } \\
\text { - Invest in technical fixes } \\
\text { and single-factor solutions }\end{array}$ & $\begin{array}{l}\text { - Appeal to pleasure } \\
\text { - Build brand value over nutritional } \\
\text { value } \\
\text { - Exploit vulnerable groups (e.g. } \\
\text { children and low income) }\end{array}$ & $\begin{array}{l}\text { - Produce an excess of } \\
\text { inappropriate, energy- dense } \\
\text { foods cheaply } \\
\text { - Offer only limited } \\
\text { investments in workforce } \\
\text { training }\end{array}$ & $\begin{array}{l}\text { - Promote fossil-based fuels } \\
\text { - Glamorise private motor transport } \\
\text { rather than expenditure of } \\
\text { food-as-energy }\end{array}$ & $\begin{array}{l}\text { - Market and mould mass } \\
\text { consciousness } \\
\text { - Barrage consumers with } \\
\text { energy-dense food and } \\
\text { drink as entertainment }\end{array}$ \\
\hline Governments & $\begin{array}{l}\text { - Adopt inconsistent modes } \\
\text { of protection (interventions } \\
\text { on sexual protection but not } \\
\text { nutrition) } \\
\text { - Are unwilling to } \\
\text { modernise public health } \\
\text { scope and capacity }\end{array}$ & $\begin{array}{l}\text { - Limit health education to become a } \\
\text { minor partner of market information, } \\
\text { generating asymmetry of information } \\
\text { flow and education }\end{array}$ & $\begin{array}{l}\text { - Subsidise overproduction of } \\
\text { fat and sugar compared with } \\
\text { micronutrient-rich foods } \\
\text { - Emphasize food safety while } \\
\text { semi-abandoning nutrition } \\
\text { - De-emphasize nutrition and } \\
\text { food education }\end{array}$ & $\begin{array}{l}\text { - Oversee decline of physical activity } \\
\text { (transport, public spaces, sports } \\
\text { facilities) } \\
\text { - Prioritise car use in retail and } \\
\text { transport planning }\end{array}$ & $\begin{array}{l}\text { - Permit genderised and } \\
\text { inadequate food literacy and } \\
\text { skills } \\
\text { - Promote rights of } \\
\text { individualized choice } \\
\text { - Facilitate media } \\
\text { transmission by paid } \\
\text { marketing } \\
\text { - Confuse citizenship with } \\
\text { marketplace meritocracy } \\
\text { (everyone is equal in the } \\
\text { market) }\end{array}$ \\
\hline Consumers & $\begin{array}{l}\text { - Disconnect appetite from } \\
\text { need and satiety }\end{array}$ & $\begin{array}{l}\text { - Adopt distorted images of body } \\
\text { acceptability } \\
\text { - Accept temporality (short-termism) } \\
\text { of choice }\end{array}$ & $\begin{array}{l}\text { - Eat a price-led rather than } \\
\text { nutrition-led diet } \\
\text { - Respond individually rather } \\
\text { than en masse to identity crises } \\
\text { about meaning and values }\end{array}$ & $\begin{array}{l}\text { - Bow to the ubiquity of the } \\
\text { non-energy-expending material } \\
\text { world (e.g. in travel to } \\
\text { work/shop/school) } \\
\text { - Are disinclined to build exercise } \\
\text { into daily life }\end{array}$ & $\begin{array}{l}\text { - Consume rather than } \\
\text { expend energy as the norm } \\
\text { of consumer culture } \\
\text { - Participate in physical } \\
\text { activity by proxy (TV } \\
\text { sports) } \\
\text { - Accept inequalities or } \\
\text { indulge in victim-blaming }\end{array}$ \\
\hline
\end{tabular}

Individuals tend to ignore that the way we approach or manage the process of change, and potentially weight loss, plays an important role. As discussed by Strecher et al. (1995), setting goals can have beneficial effects in health behaviour change and maintenance interventions. Cognitive behavioural therapy (CBT) strategies include specific goal setting, self-monitoring, feedback and reinforcement from outside sources, boosting the confidence in succeeding as well as the use of incentives.

\section{Fad Diets}

As a consequence, people are more susceptible to adopt various fad diets that claim to aid in losing weight very fast. As stated in CDC's "Healthy Weight - It's not a diet, It's a lifestyle!" a fad diet is any weight loss plan that promises quick results and is usually a temporary nutritional change (Centers for Disease Control and Prevention [CDC], 2014). These diets are considered unhealthy as they provide individuals with less calories and nutrients.

\subsection{History of Fad Diets}

Fad diets are known for centuries. Since ancient times, it was reported that Greeks and Romans had used them; however, at that time it was more about a healthy and active lifestyle. It was Victorians later who actually adopted fad diets. According to Foxcroft (2011) in her book 'Calories \& Corsets: A History of Dieting Over 2 000 Years', the word diet originates from the Greek word diaita, which represents a way of life including mental and physical health. It was in the $19^{\text {th }}$ century that people started dieting for aesthetic purposes.

One of the most famous dieter of all time was Lord Byron, who in 1820 made the Vinegar and Water Diet very popular (Foxcroft, 2011). A century later, the Grapefruit Diet was created, where eating grapefruit with each meal was suggested as part of a low calorie diet plan. Interestingly, the Lucky Strike cigarette company launched the known Cigarette Diet based on the appetite suppressing effects of nicotine. Later in 1963, Jean Nidetch 
founded Weight Watchers and in 1970 the 'sedative' Sleeping Beauty Diet became famous (Rotchford, 2013). The last few decades, fad diets, such as The Atkins and Dukan Diets, became well known, based on high-protein and low-carbohydrate intake (Hughes, 2012). Other examples include the Zone Diet, suggesting a certain ratio of fat protein and carbohydrates, the South Beach Diet, which is a lighter version of Atkins Diet and the Master Cleanse, a diet based mostly in liquid food (Rotchford, 2013). Figure 1 demonstrates the most important diets throughout history.

\subsection{How to Identify a Fad Diet}

A fad diet is usually described as a weight loss plan that guarantees quick weight loss and dramatic results with no much effort. There are various types of fad diets that can be recognized; however, all of them share some common characteristics (Bastin, 2004). All fad diets promise fast weight loss (more than $1 \mathrm{~kg}$ a week) without giving away fatty, rich-in-calories food and without the need to regularly exercise. Most fad diets limit the range of food types included in the meal plan and do not reassure a balanced and healthy diet. They usually propose 'miracle' foods that need to be consumed in abnormal quantities and help fat burning with a minimal effort. Some focus on consuming large quantities of one food type that could result in intestinal disturbance, bloating, bad breath and nutritional imbalances (Bastin, 2004).

Fad diets are usually promoted by 'before and after' images of successful examples of people that have followed the particular diet or by 'experts' in the field of nutrition. However, no health warnings about possible consequences of adopting these fad diets on individuals with chronic diseases are included in the advertisements. Most fad diets are usually based in no or limited research and can lead to serious health impacts (Bastin, 2004).

\subsection{Popular Fad Diets}

As mentioned before, there is a wide range of proposed fad diets over the last centuries, which are summarised in Tables 2 and 3. They can be categorised into several main groups including low-/no- carbohydrate, high-carbohydrate/high-fibre as well as the liquid formula diets (Bastin, 2004; British Dietetic Association [BDA], 2014).

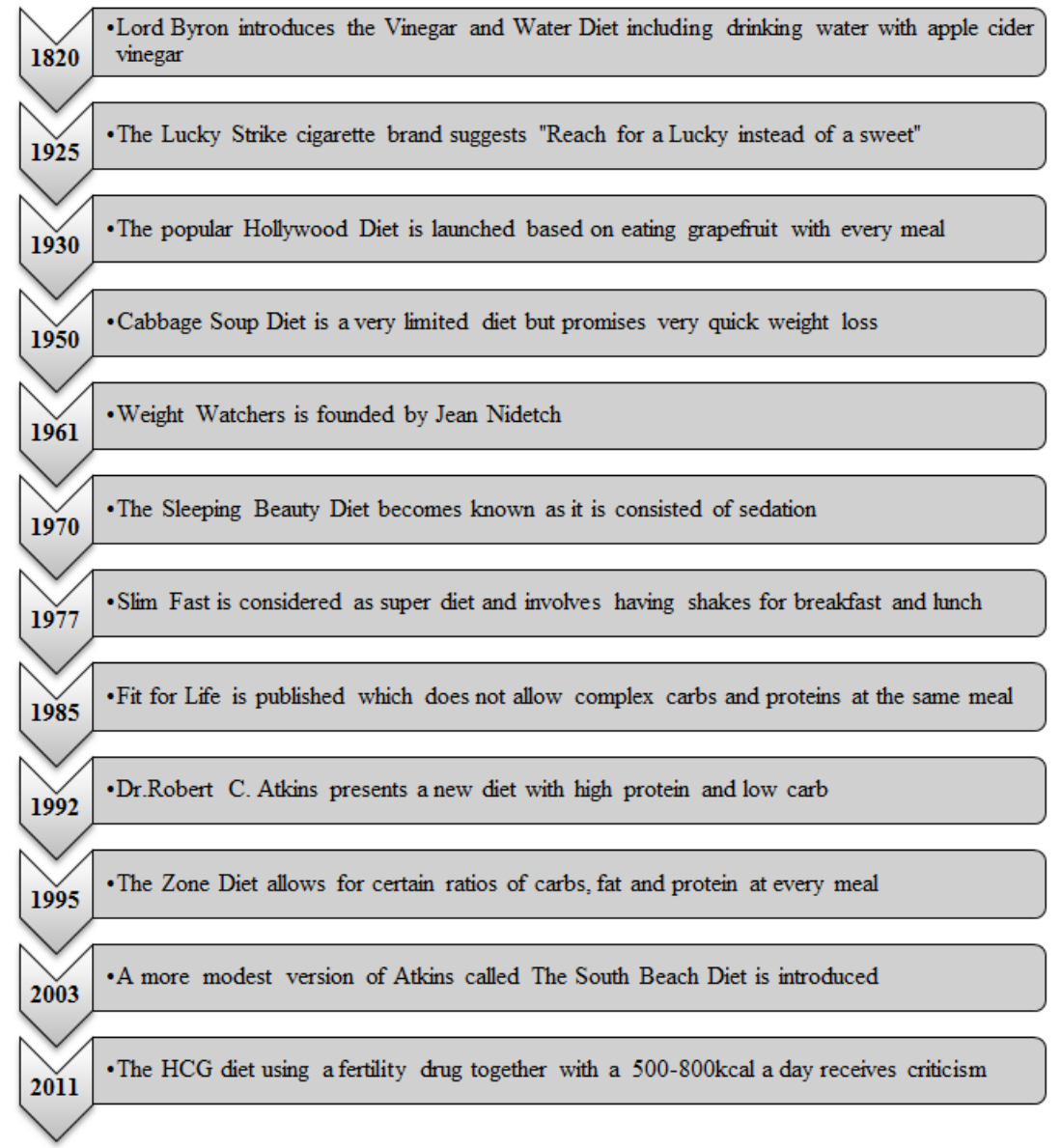

Figure 1. History of dieting over time including the most popular fad diets (adjusted from Rotchford, 2013) 
When following a low- or no-carbohydrate diet, a high intake of protein and/or fat is recommended. Example fad diets of this type include the Atkins diet, the Dukan diet, the South Beach diet and the Grapefruit diet. These diets are particularly popular as due to the low intake of energy through carbohydrates, a rapid weight loss mainly due to water loss occurs immediately. The success of such a 'ketogenic' diet together with high protein consumption promotes great weight loss by increasing satiety, which makes it easier to adhere (Geissler \& Powers, 2005). However, it is common that the weight is gained back once the diet is discontinued as the body tries to 'correct' the water imbalance (Bastin, 2004) (Figure 2). Although the diet's claimed weight loss compared to conventional energy-restricted diets has been demonstrated in controlled trials (Foster et al., 2003), its long-term effects are still being investigated by the scientific community.

These diets can be quite dangerous due to the ketone formation in excess amounts as a result of incomplete fat breakdown and dehydration. Ketones are stored in blood and can even lead to death if the diet is continued long-term. The Recommended Dietary Allowance (RDA) for carbohydrates is 130 grams per day for both adults and children as an average minimum intake of glucose used by the brain for normal function (Food and Nutrition Board, Institute of Medicine, 2005).

Table 2. Types of fad diets (adjusted from Bastin, 2004; BDA, 2014)

\begin{tabular}{|c|c|}
\hline Diet type & Known examples \\
\hline Low carbohydrates $(<100 \mathrm{~g} / \mathrm{day})$ & $\begin{array}{l}\text { - Atkins Diet Revolution } \\
\text { - South Beach Diet }\end{array}$ \\
\hline Extremely low fat $(<20 \% \mathrm{kcal}$ from fat $/$ day $)$ & $\begin{array}{l}\text { - Pritikin Diet } \\
\text { - Pasta Diet }\end{array}$ \\
\hline Combination & $\begin{array}{l}\text { - Fit for Life } \\
\text { - Zone Diet }\end{array}$ \\
\hline Very low kcalorie ( $<800 \mathrm{kcal} / \mathrm{day})$ & $\begin{array}{l}\text { - Cambridge Diet } \\
\text { - Rotation Diet }\end{array}$ \\
\hline Novelty (certain nutrients or foods) & $\begin{array}{l}\text { - Beverly Hills Diet } \\
\text { - Junk Food Diet }\end{array}$ \\
\hline Formula & $\begin{array}{l}\text { - Slim Fast } \\
\text { - Last Chance Diet }\end{array}$ \\
\hline Pre-measured & $\begin{array}{l}\text { - Jenny Craig } \\
\text { - Nutri-System }\end{array}$ \\
\hline Detox & - The Master Cleanse \\
\hline High fat & - Ketogenic Diet \\
\hline High protein & $\begin{array}{l}\text { - Dukan Diet } \\
\text { - Bodybuilder Diet }\end{array}$ \\
\hline
\end{tabular}

Table 3. Main categories of fad diets as suggested by the BDA

\begin{tabular}{llll}
\hline High-protein & Moderate-fat & Low-fat & Very-low-calorie \\
Low-Carbohydrate & Low-carbohydrate & Very-high-carbohydrate & \\
\hline Atkins & Jenny Craig & Ornish & Bernstein \\
Dukan & Nutri-System & The New Pritikin program & Lighter Life \\
South Beach & Weight Watchers & LEARN & Slim Fast \\
Zone & & & \\
\hline
\end{tabular}

On the other hand, high-carbohydrate/high-fibre-diets are also popular, including the Pritikin diet plan and Save-Your-Life diet. This type of diets provide with low levels of both proteins and fats, which can lead to reduced immunity and problematic wound healing (Bastin, 2004). Furthermore, the liquid formula diets contain very limited calorie intake (often 400-500 calories) and promise to supply with the necessary nutrients. An example of a very low-calorie diet is the Cambridge diet. These diets should be adopted with caution as the self-prescribed starvation be linked with health risks and serious illnesses such as anaemia, reduction of vitamins and minerals supply, fatigue as well as weakness and dizziness. Lastly, diets suggesting the consumption of only one food group like the Cider Vinegar and Vitamin $\mathrm{B}_{6}$ Diet are also popular but can cause malnutrition and reduced renal function (Bastin, 2004). 


\section{Causes Leading to Fad Dieting}

\subsection{The Effect of Peer Pressure}

Following a fad diet is often a result of peer pressure. Peer pressure occurs when people of the same age influence an individual's behaviours and decisions by making the person feeling uncomfortable, including the way of thinking of themselves, dressing and eating. Peer pressure originates not only from family and friends but also from the outside environment (Berry, 1999). Criticism of weight and diet by peer members is associated particularly with dieting in teenagers (Cattarin \& Thompson, 1994). The ideal body image introduced by peers can lead to feelings of inferiority, low self-esteem and depression. Emotions of guilt and unattractiveness are strongly developed causing individuals to adopt fad diets to make themselves more likable. These individuals appear to be obsessed with their appearance, weight and popularity within their peers that results in inefficient dieting (Berg, 1996).

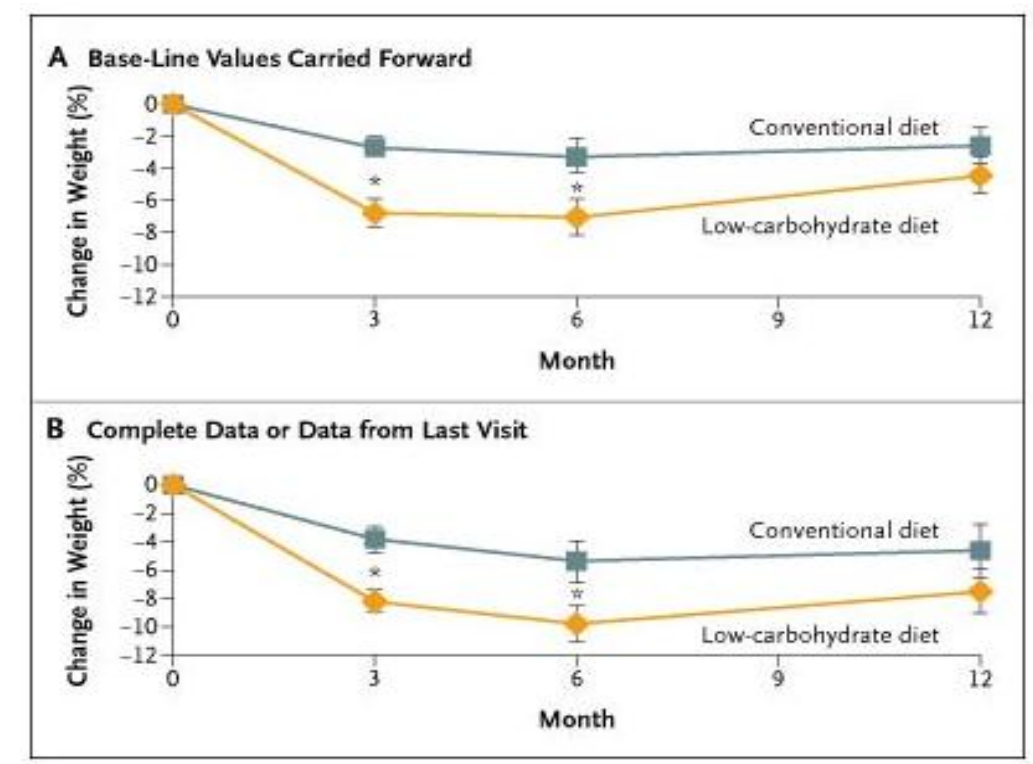

Figure 2. Average weight changes amongst subjects on a low-carbohydrate diet and a

low-calorie/high-carbohydrate conventional diet (adapted from Foster et al., 2003)

Furthermore, possible failed attempts to quickly lose weight can lead to depression and 'yo-yo' dieting. Extreme weight loss followed by quick weight gain is associated with many health risk factors such as heart disease, cancer, diabetes, increased in LDL cholesterol as well as reduced muscle and energy. It is believed that these negative health impacts are linked with the stress hormone called cortisol (McNight, 2013). These feelings and continuous dieting can result in unhealthy eating habits, which can continue over someone's lifetime (Berry, 1999). The fear of being fat can also lead to eating disorders from a young age, such as anorexia nervosa and bulimia. In both disorders, sufferers show body image distortions and feelings of anxiety and shame about eating (Human Diseases and Conditions [HDC], 2014).

\subsection{The Effect of Media on Body Image and Self-Esteem}

Over the last decade, statistics have shown an increase in people suffering from eating disorders in many societies due to the continuous value that they put on being thin. In every aspects of someone's life, such as going for shopping, watching television, reading fashion magazines and following favourite celebrities, the very thin figure is linked with a happy and successful life. Therefore, thousands of teenagers are exposed to the 'ideal', unrealistic image of models, who according to medical standards, try to maintain a $15 \%$ below normal weight and meet the criteria for anorexia (Mirror Mirror Eating Disorders [MMED], 2014). Television, movies and social media are full of diet advertisements about food supplements, diet programs and in general chemically based ways to lose weight. Every month new novel diets promise to cause dramatic changes to the appearance of overweight people; probably due to the fact that all previous diets did not work and are rather unhealthy (MMED, 2014). The inevitable effects of food advertising on eating behaviours was studied in elementary-school-aged children which received a snack after watching a cartoon with either a food advertisement or one about other products (Harris, Bargh, \& Brownell, 2009). The results showed that children consumed $45 \%$ more snacks (28.5 gr) when exposed to the food advertisements than their controls (19.7 gr) (Harris et al., 2009). 
Apart from advertisements, television and fashion magazines also include articles or reports about appearance meaning how to look perfect, how to be in shape, how to apply makeup or suggestions about clothing. Magazines are also full of photos that have previously been photo-shopped containing wrinkle-free faces and fat-free bodies which are idealistic and far from reality (Education.com, 2014). A study has found that 69\% of teenage girls agreed that the photos in magazines affected their idea of the 'ideal' body image, while $47 \%$ said that as a result they desired to lose weight (Field, 2000). The frequency of reading magazine's articles about weight loss and diets increases the possibilities of adopting unhealthy eating and weight control behaviours like skipping meals and fasting, especially among teenagers (Van den Berg, Neumark-Sztainer, Hannan, \& Haines, 2007).

\section{Weighing Short-Term Pros against Long-Term Cons}

Table 4 summarises the advantages and drawbacks of the main categories of fad diets, which are discussed in more detail below.

Table 4. Advantages and disadvantages of fad diets as suggested by the BDA (2014)

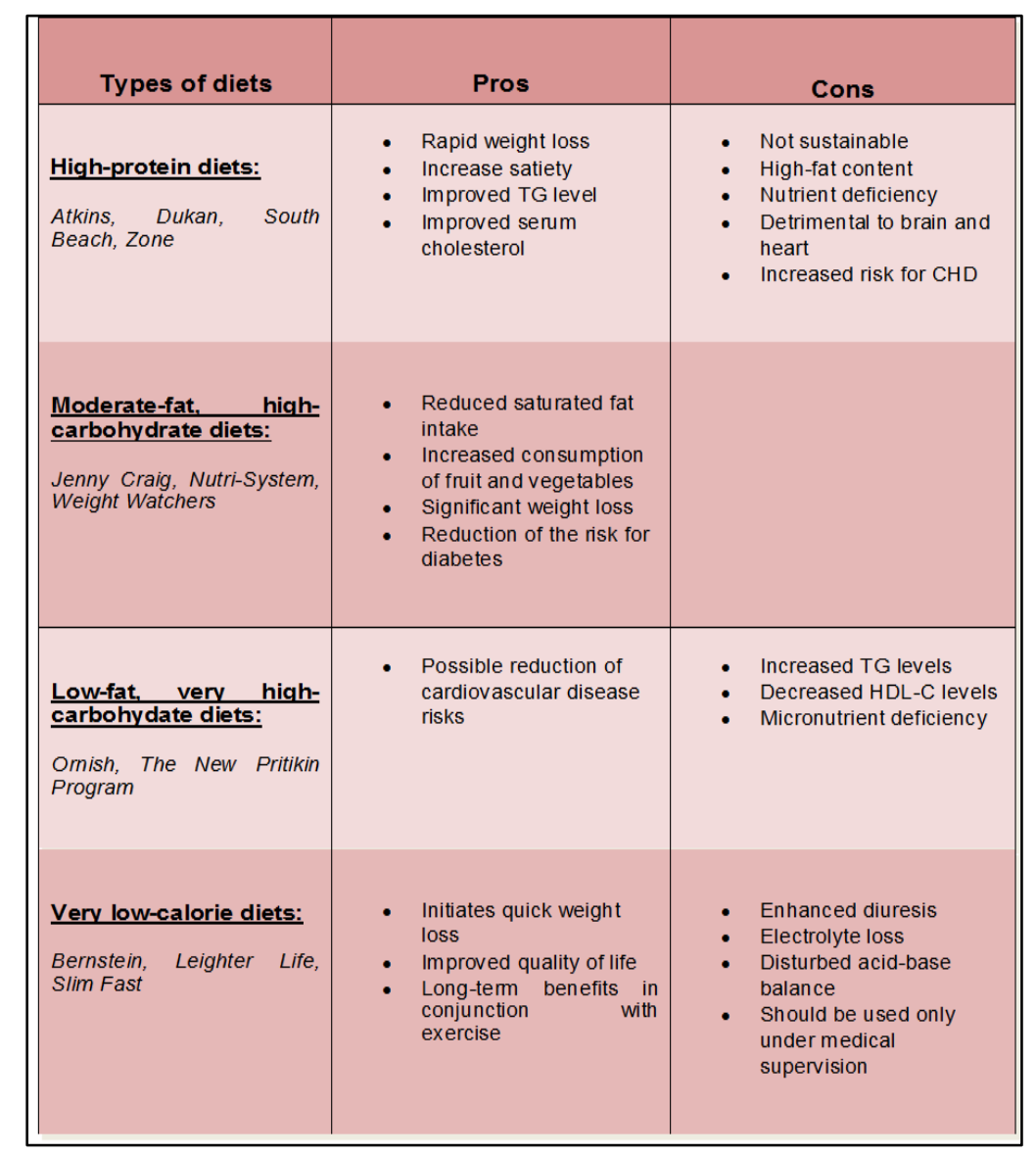

\subsection{Benefits of Fad Diets}

Fad diets are usually known for showing drastic results and some of them can actually offer some benefits. There are plenty of benefits when following a low-carbohydrate diet. Atkins diet is known for the suppression of appetite and its anorectic properties, mainly due to the high protein intake (McClernon, Yancy, Eberstein, Atkins, $\&$ Westman, 2007). It results in a rapid weight loss, especially during the first few weeks. In a controlled study of 63 obese patients, Atkins diet resulted in a weight loss of $6.8 \%$ body weight after three months compared to $2.7 \%$ accomplished by an energy-restricted diet (Foster et al., 2003). Low-carbohydrate diets have also a great potential in eliminating a larger proportion of abdominal fat (Volek et al., 2004). In addition, carbohydrate restriction can be efficient in significantly lowering both the plasma LDL cholesterol and triglyceride following a twelve-week weight loss intervention (Wood et al., 2006). At the same time, HDL levels can be dramatically increased because of the high-fat consumption included in Atkins diet (Brinkworth, Noakes, Buckley, Keogh, \& Clifton, 2009). Furthermore, in a study testing the effect of a low-carbohydrate diet in type 2 diabetes, it was 
reported that most patients improved their glycemic index and reduced or eliminated medication control within six months (Westman et al., 2007). Lastly, Atkins diet has shown to reduce blood pressure short-term, therefore leading to a decreased risk of developing cardiovascular diseases (Gardner et al., 2007).

The proposed meal plans such as in many Detox diets or the Grapefruit diet often consist of lots of fruits and vegetables. These food types are popular for being healthy and beneficial but of low calories at the same time. Fad diet users will therefore supply with many vitamins, minerals and antioxidants. Following these eating habits also helps in promoting physical and psychological health. A person that loses weight firstly reduces the risks linked with obesity and secondly feels lighter, healthier and with increased self-confidence (Health Research Funding [HRF], 2014). Moreover, adopting a fad diet can help someone recognise which characteristics of his/her current diet are responsible for the excess weight. Fad diet programs like the French Woman's diet can also help establish the right portion sizes and avoid unwanted snaking (Cespedes, 2014).

\subsection{Health consequences of fad dieting}

On the other hand, fad diets do not come without disadvantages. Weight loss occurs too fast, most of the lost weight being water and muscle, not fat tissue. Rapid weight loss can further lead to various health risks such as constipation, low nutrients and energy intake and tiredness, all caused by eating less calories (HRF, 2014).

Fad diets, especially the low-carbohydrate/high-protein diets such as The Dukan diet, involve physiological aspects; they limit the amount of carbohydrate and sugar intake and at the same time promote the consumption of animal protein. As a result, there is a shift from using glucose to using fatty acids and ketones as the main fuel sources; therefore, the glycogen availability increases (Westman et al., 2007). Ketosis could then result in a decrease of appetite but also cause hyperuricemia since ketones compete with urine acid for renal tubular excretion (Denke, 2001). Despite the reputation of the ketogenic diets there is little scientific support of their long-term side effects and sustainability. In order to suggest the adaptation of such diets as a 'life nutritional philosophy', possible adverse effects on health and disease prevention need to be studied.

Studies have shown that high-fat/high-protein diets like The Atkins diet also result in higher risk of heart disease (WHO/Food \& Agriculture Organisation Expert Consultation, 2013), colon cancer (Giovannucci et al., 1994), bad breath (Mahon \& Escott-Stump, 1996) and sleeping disorders (Fitness, 2014). Anderson, Konz, and Jenkins (2000) showed that the Atkins diet increase the cholesterol levels in the serum, increasing the risk of atherosclerosis and coronary heart disease by greater than $50 \%$ if used in long term. Various adverse effects of following a very-low-carbohydrate short-term diet have previously been reported including constipation due to low fibre intake (68\% of participants), bad breath (63\%), headache (51\%), hair loss $(10 \%)$ and increased menstrual bleeding (3\%) (Westman, Yancy, Edman, Tomlin, \& Perkins, 2002).

High-protein diets have been linked with a greater production of nitrogen waste products, which add a pressure on the kidneys, especially in dehydration state (Denke, 2001). Another study has shown that after six weeks of such a diet there is an increased acid load to the kidney maximising the possibility of stone formation and a decrease of calcium balance leading to bone loss and osteoporosis (Reddy, Wang, Sakhaee, Brinkley, \& Pack, 2002). Consuming two or three times more protein than the recommended daily allowance has been associated with loss of calcium through the urinary tract, which could predispose to bone loss long-term (Eisenstein, Roberts, Dallal, \& Saltzman, 2002). Although significant reduction in insulin responses has been observed after a low-carbohydrate diet (Westman et al., 2007), it is believed that insulin sensitivity and resistance may be negatively influenced in the long-term (Riccardi, Giacco \& Rivellese, 2004; Shulman, 2000). Moreover, following such a diet for several months can cause an increase in plasma homocysteine (Clifton, Noakes, Foster, $\&$ Keogh, 2004), the effect of which has been linked with higher cardiovascular risk (Refsum, Ueland, Nygard, \& Vollset, 1998).

On the other hand, low-protein/low-fat diets might increase the risk of inadequate intake of minerals such as calcium and zinc as well as high-quality protein. For example when following the Pritikin diet the recommended fat intake should be less than $10 \%$ of the daily energy intake which is close to the lowest limit of the daily requirement for essential fatty acids (Pritikin, 1981). Other nutritional deficiencies, such as iron deficiency, can be associated with growth decrease and anaemia in adolescents (Dietz \& Hartung, 1985). Additionally, adopting unbalanced eating habits has been connected with menstrual irregularity or amenorrhea (Kreipe, Strauss, Hodgman, \& Ryan, 1989). Table 5 summarises the most popular fad diets, their main components and their physiological implications, the main of which are explained below.

\subsection{Psychological Implications}

Studies in adults have suggested that constant dieting (yo-yo dieting) is associated with a range of symptoms 
such as food obsession, constant calorie counting, distractibility, increased emotional responsiveness and fatigue (Polivy, 1996). Chronic dieters also tend to overeat, have low self-esteem as well as suffer from some eating disorders and depression (Polivy, 1996). It is known that these effects are particularly true in children and teenagers, causing complicated consequences in their social and psychological development (Canadian Paediatric Society [CPS], 2004). From previous studies it has been shown that following a structured, multidisciplinary weight loss regime might have a negative effect on the self-esteem of both children (Cameron, 1999) and adolescents (Stice, Cameron, Killen, Hayward, \& Taylor, 1999). Current research has linked dieting with higher risk of developing disordered eating as well as a trend to overeat; however, the causes are still unclear or controversial (Polivy, 1996). Lastly, self-directed dieting early in life (9-14 years old) has been associated with weight gain overtime in large-scale, 3-year-long study involving more than 15000 subjects (Field et al., 2003).

\subsection{Safety of Fad Diets}

Fad diets promise quick weight loss but are generally thought to be unhealthy and temporary. Weighing the advantages over the drawbacks of fad dieting can be hard but necessary since there is no scientific evidence proving their safety. According to NHS (2013) in 2011 the BDA had warned against many fad diets since they were not based on clinical trials and reportedly did not give rise to long-term results. Also, most of these diets overemphasise one particular food type (for example the Banana or the Rice diet) and are considered dangerous and nutritionally unbalanced. Furthermore, there is not always supplementary scientific evidence to support the proposed claims (Fisher, 2011).

\section{Sustainability of Weight Loss by Fad Diets}

Furthermore, the strict regime of fad diets makes it very difficult to commit as eating low-calorie foods requires both preparation and lifestyle change (HRF, 2014). It is common that most of dieters regain the weight they have lost - or even more within a few months - a situation that leads to yo-yo dieting. It is believed that it is very hard to maintain a fad diet long-term as the dieters revert back to their previous eating habits at some point. Thomas, Hyde, Karunaratne, Kausman, and Komesaroff (2008) conducted a study on obese subjects and found that they were unable to commit to these diets for various reasons such as unsuitable or costly diet, concordance with their lifestyle and monotony in food choices.

Foster et al. (2003) showed that although following a low-carbohydrate diet produced a larger weight loss compared to the conventional diet at six months period, the difference was not statistically significant after a year. Moreover, these findings are supported by a study published in 2006 from the BBC "diet trials". This randomized controlled study compared the effectiveness of four popular fad diets in the UK over six months including the Dr Atkins' new diet revolution, the Slim-Fast plan, the Weight Watchers pure points plan, and the Rosemary Conley's eat yourself slim diet and fitness plan (Truby et al., 2006). The trial was based in 293 healthy overweight or obese adults, who all succeed a significant loss of both weight and body fat regardless of the fad diet followed. Although the Dr Atkins' new diet revolution resulted in higher weight loss during the first month, there were no statistically significant differences among the diet plans after 6 months. The study also showed that the initial sustainability was not feasible over a long period of time as demonstrated in Figure 3 . These findings are also supported by the review conducted by Jebb and Goldberg (1998); however, it was also shown that there was a small portion of participants (3-4\% based on 381 subjects) that were still $30 \%$ or more below baseline after 5 years and actually managed to maintain their weight loss. Nevertheless, it should be noted that these individuals had incorporated physical activity and meal replacement into their lifestyle (Jebb \& Goldberg, 1998). 
Table 5. Popular fad diets and their health consequences

\begin{tabular}{|c|c|c|c|c|}
\hline Type of diet & Example & $\begin{array}{l}\text { Summary/Main } \\
\text { components }\end{array}$ & Health consequences & References \\
\hline $\begin{array}{l}\text { Low-carbohydrate/ } \\
\text { High-protein }\end{array}$ & Atkins diet & $\begin{array}{l}\text { Less than } 50 \mathrm{~g} \text { CHO per } \\
\text { day, high consumption of } \\
\text { animal protein } \\
\text { Carb-free, high in protein } \\
\text { diet structured in four } \\
\text { different phases }\end{array}$ & $\begin{array}{lr}\text { Water } & \text { imbalance, } \\
\text { ketosis, } & \text { appetite } \\
\text { suppression, } & \text { renal } \\
\text { dysfunction, nausea, low } & \text { performance } \\
\text { dehydration, } & \\
\text { osteoporosis } & \end{array}$ & $\begin{array}{l}\text { Diabetes.co.uk } \\
(2011)\end{array}$ \\
\hline $\begin{array}{l}\text { High-carbohydrate/ } \\
\text { Low-fat }\end{array}$ & $\begin{array}{l}\text { Pritikin } \\
\text { diet }\end{array}$ & $\begin{array}{l}\text { Low-fat, low-calorie, } \\
\text { plant-based foods, mainly } \\
\text { fruits and vegetables, fats } \\
\text { not exceeding } 10 \% \text { of } \\
\text { total daily calories }\end{array}$ & $\begin{array}{l}\text { Inadequate intake of } \\
\text { good quality protein, } \\
\text { vitamin and mineral } \\
\text { deficiencies, coronary } \\
\text { heart disease }\end{array}$ & Pritikin (1981) \\
\hline $\begin{array}{l}\text { Low carbohydrate/ } \\
\text { High-fat }\end{array}$ & $\begin{array}{l}\text { Ketogenic } \\
\text { diet }\end{array}$ & $\begin{array}{l}\text { High-fat, } \\
\text { adequate-protein, } \\
\text { low-carbohydrate diet } \\
\text { changing the way energy } \\
\text { is used in the body }\end{array}$ & $\begin{array}{l}\text { Acidosis, hypoglycemia, } \\
\text { gastrointestinal distress, } \\
\text { dehydration, lethargy, } \\
\text { kidney stones, } \\
\text { dyslipidemia, decreased } \\
\text { bone density }\end{array}$ & $\begin{array}{l}\text { Freeman, } \\
\text { Kossoff, \& \& } \\
\text { Hartman (2007) }\end{array}$ \\
\hline Combination & Zone diet & $\begin{array}{l}\text { Hormonal control } \\
\text { (insulin, glucagon and } \\
\text { eicosanoids) via a specific } \\
\text { ratio of protein, CHO and } \\
\text { fat intake }\end{array}$ & $\begin{array}{l}\text { Vitamin and mineral } \\
\text { deficiencies }\end{array}$ & $\begin{array}{l}\text { Sears \& Lawren } \\
(1995)\end{array}$ \\
\hline One-food & $\begin{array}{l}\text { Grapefruit } \\
\text { diet }\end{array}$ & $\begin{array}{l}\text { Certain combinations of } \\
\text { food with grapefruit and } \\
\text { grapefruit juice, no } \\
\text { sugary/starchy } \\
\text { allowed food }\end{array}$ & $\begin{array}{l}\text { Unbalanced nutrition, } \\
\text { interfere with certain } \\
\text { medication, risk for } \\
\text { increase intake of } \\
\text { saturated fat, sodium and } \\
\text { cholesterol. }\end{array}$ & Ipatenco (2014) \\
\hline Formula & $\begin{array}{l}\text { Slim Fast } \\
\text { diet }\end{array}$ & $\begin{array}{l}\text { Dietary supplement based } \\
\text { on a drinkable meal } \\
\text { replacement once or twice } \\
\text { a day, each containing } \\
\text { around } 240 \mathrm{kcal}\end{array}$ & $\begin{array}{l}\text { Low nutritional intake, } \\
\text { low energy, weakness, } \\
\text { risk for eating disorders }\end{array}$ & Stern (2015) \\
\hline
\end{tabular}

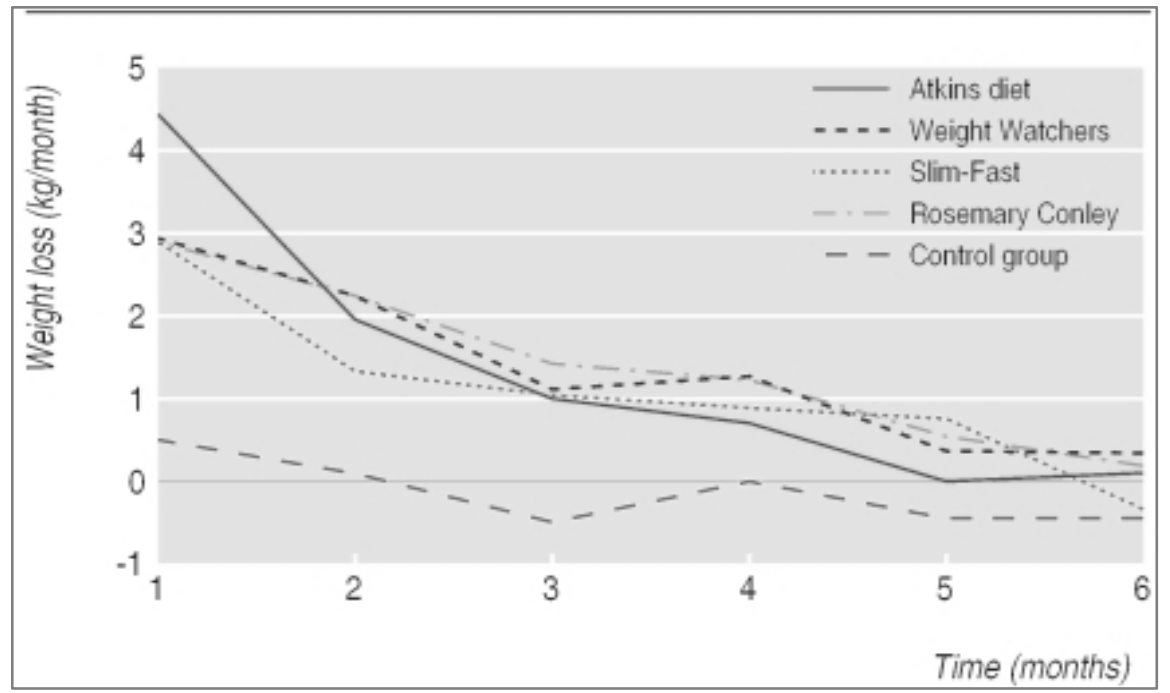

Figure 3. Weight loss over six months after following four commercial weight loss programs in UK (Source:

Truby et al., 2006) 


\section{Fibre-Enriched Diets and Weight Management}

As shown above, although following a fad diet could result in rapid weight loss within the first few weeks, the sustainability of the achieved results is very low. It should be mentioned that adjusting daily dietary habits and physical activity is the key to weight management including weight loss and maintenance. To gain the required knowledge and positively progress towards long-term weight loss, one has to go through various stages of adaptation such as commitment to change and self-efficacy. Temporary changes of eating habits only leads to temporary weight loss results and to overcome fad dieting drawbacks, a high-in-fruits-and-vegetables (50\%) but low-in-fat-and-sugars $(<30 \%)$ diet has been recommended by various researchers (National Institutes of Health [NIH], 1998).

It is commonly believed that a high-fruit diet is ideal for weight loss since fruits are known to have unique properties and play an important part of a healthy and balanced diet (He et al., 2004). Fruits are high-in-water, high-in-sugar, low-in-fat and high-in-fibre, have only a few calories as well as essential minerals, vitamins and antioxidants (Martin, Cherubini, Andres-Lacueva, Paniagua, \& Joseph, 2002; Swinburn, Caterson, Seidell, \& James, 2004). Both soluble and insoluble fibres are found in considerable amounts in fruits (especially in fruits' skins) and have been reported to help with weight management (Pereira, \& Ludwig, 2001). Researchers have shown that dietary fibre increases post-consumption satiety and also decreases following hunger (Howarth, Saltzman, \& Roberts, 2001). Therefore, by eating fruits with low energy density rather than foods with high energy density, one can eat greater amounts but the same calorie content (CDC, 2015). Howarth et al. (2001) have shown that by increasing the daily fibre intake to an extra $14 \mathrm{gr}$ per day for two days decreased the energy intake by $10 \%$ and resulted in $\sim 2 \mathrm{~kg}$ weight loss over 4 months. Furthermore, soluble fibre has a beneficial impact in controlling post-meal glycaemic and insulin responses as it affects gastric emptying and how macronutrients are absorbed by the gut (Babio, Balanza, Basulto, Bulló, \& Salas-Salvadó, 2010).

Given all the benefits of increased fruit intake mentioned above, researchers have introduced and tested various interventions to prevent or tackle obesity. As an example, Tohill (2005) summarised a large number of epidemiological studies on the relationship of fruit intake and BMI on both children and adults. It has been proven that a high fruit and vegetable intake (two servings of fruits and three servings of vegetables a day) is associated with a decrease in high fat and sugar intake (less than 10 servings of high-fat/high-sugar foods per week), potentially helpful in families with obesity history (Epstein et al., 2001). Moreover, in contrast with fad diets, as illustrated after a 4-year-long intervention, individuals can sustain drastic dietary changes that mainly include high-fibre, low-fat food provided the appropriate support (Lanza et al., 2001).

\subsection{Health Benefits of Dietary Fibre}

Various observational and experimental studies have shown that there is a positive link between higher fibre intake and lower risk of many health risk factors. Increasing dietary soluble fibre results in the reduction of various biochemical parameters such as total and LDL cholesterol and can be introduced as a small contributor to dietary therapy to lower blood cholesterol (Brown, Rosner, Willett, \& Sacks, 1999). Similarly, greater dietary fibre intake has been associated with a lower risk of both cardiovascular disease and coronary heart disease in a total of 22 cohort studies (Threapleton et al., 2013).

Also, better kidney function as well as reduced inflammation is considered one of the health benefits of soluble fibre (Xu et al., 2014). It is known that rich-in-fibre food types contain large amounts of essential minerals such as calcium, potassium and magnesium that can lead in a higher total bone mass providing evidence of a positive association between fruit and vegetable consumption and bone health (New et al., 2000). Lastly, initial controlled trial recently conducted by our research group introducing soluble fibre in the form of a fruit salad in the daily nutritional intake has also highlighted the positive effects of increased dietary fibre in both weight management and better health.

\section{Government Public Health Initiatives}

In the UK, the National Health Service is trying to combat fad diets and obesity by informing the public on health and nutrition as well as promoting healthier eating habits for weight loss (NHS Choices, 2014). Together with the British Dietetics Association, NHS emphasises the pros and cons of popular fad diets. Also, the Medicines and Healthcare products Regulatory Agency (Medicines and Healthcare products Regulatory Agency [MHRA], 2014) is trying to prevent people from using diet drugs like the homeopathic human chorionic gonadotropin (hCG) by not authorizing it for use in the UK.

Furthermore, within the UK, the National Health Service has initiated the Change4life campaign that promotes the '5-a-day' which includes consuming at least five portions of fruit and vegetables per day as part of a balanced 
diet (Change4life, 2015). Additionally, in an attempt to tackle obesity, especially in children, the non-profit organization Mind, Exercise, Nutrition... Do it! (MEND) offers weight management programs and family support all over the UK (MEND, 2015). This program provides help designed by health professionals including nutritionists, dietitians, physical activity experts as well as behaviour change specialists through one-to-one sessions with parents and children. However, this type of initiative can last for up to 10 weeks meaning that results can only be effective and sustainable if the families take the recommendations on board.

Due to its nutritional composition, fad diets remain a subject of much controversy since the recommended daily allowance for total energy is $35 \%$ of fat, $50 \%$ of carbohydrates and $15 \%$ of proteins (Scientific Advisory Committee on Nutrition, 2015). Possibly one way forward would be to educate people on healthy practices and enable lifestyle changes. This requires realistic goals and slow weight loss followed by a balanced diet, engagement in physical activity and small portion sizes. Following the eatwell plate where $1 / 3$ of foods should be composed of fruits and vegetables, $1 / 3$ of starch, moderate amounts of dairy and meat products and occasionally small amounts of food high in fat and sugar would be a good start (Food Standards Agency [FSA], 2010) (Figure 4).

\section{Conclusion}

Fad diets have been popular for decades due to societal and peer pressure to have certain body shape. Most of them limit the range of food types included in the meal plan and do not reassure a balanced and healthy diet. They promise fast weight loss; nevertheless they suffer from many drawbacks such as introducing health risks and low sustainability. Nowadays, there are various types of fad diets available; however, individuals should be aware that there is no scientific evidence proving their safety. Fad diets have been linked with many physiological conditions such as cardiovascular disease, renal dysfunction and osteoporosis as well as psychological implications like eating disorders and depression. A long-term, high-fibre diet will overcome these complications, as the weight loss results are more likely to be sustainable. Increased dietary soluble fibre also provides with various health benefits such as better bone health in elderly populations commonly suffering from osteoporosis.

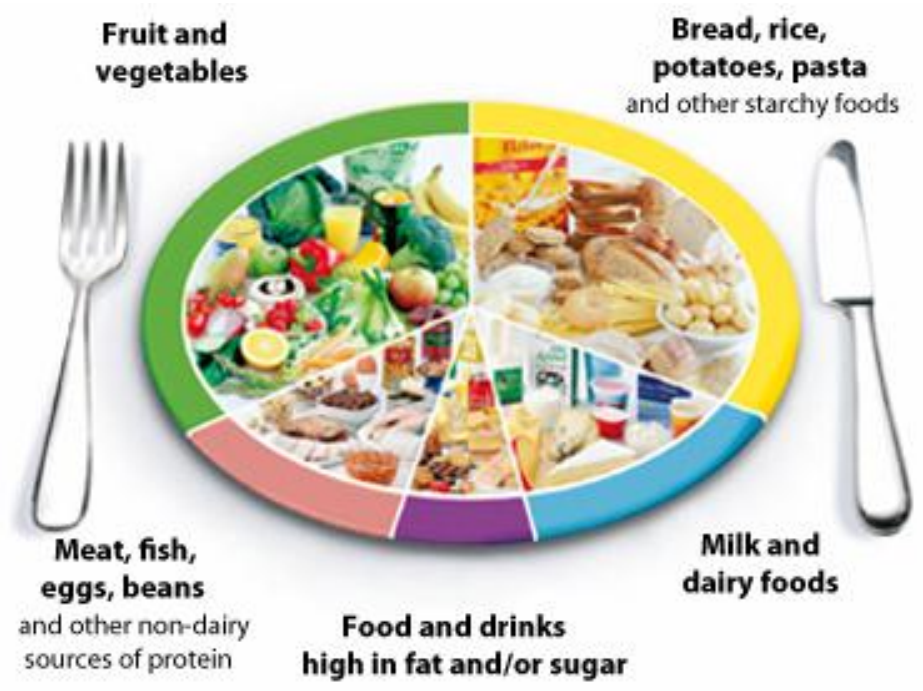

Figure 4. The eatwell plate (Source: FSA, 2010)

\section{References}

Anderson, J. W., Konz, E. C., \& Jenkins, D. J. (2000). Health advantages and disadvantages of weight-reducing diets: a computer analysis and critical review. Journal of American College of Nutrition, 19, 578-590.

Atkins, R. (1992). Dr Atkins'new diet revolution. New York, NY: Avon.

Babio, N., Balanza, R., Basulto, J., Bulló, M., \& Salas-Salvadó, J. (2010). Dietary fibre: influence on body weight, glycemic control and plasma cholesterol profile. Nutrición Hospitalaria, 25(3), 327-340.

Bastin, S. (2004). Fad Diets. Available at: http://www2.ca.uky.edu/hes/fcs/factshts/fn-ssb.119.pdf

Berg, F. (1996). Children in weight crisis. Healthy Weight Journal, 10(5), 86-87.

Berry, L. (1999). Media and peer influence on fad diets tried by adolescent females. University of Wisconsin-Stout. Available at: http://www2.uwstout.edu/content/lib/thesis/1999/1999berry.pdf 
Brinkworth, G. D., Noakes, M., Buckley, J. D., Keogh, J. B., \& Clifton, P. M. (2009). Long-term effects of a very-low-carbohydrate weight loss diet compared with an isocaloric low-fat diet after 12 mo. American Journal of Clinical Nutrition, 90(1), 23-32. http://dx.doi.org/10.3945/ajen.2008.27326

British Dietetic Association. (2014). Food Fact Sheet - Detox Diets. Available at: https://www.bda.uk.com/foodfacts/detoxdiets

Brown, L., Rosner, B., Willett, W. W., \& Sacks, F. M. (1999). Cholesterol-lowering effects of dietary fiber: a meta-analysis. American Journal of Clinical Nutrition, 69(1), 30-42.

Cameron, J. W. (1999). Self-esteem changes in children enrolled in weight management programs. Issues in Comprehensive Pediatric Nursing, 22(2-3), 75-85. http://dx.doi.org/10.1080/014608699265301

Canadian Paediatric Society. (2004). Dieting in adolescence, Paediatrics \& Child Health, 9(7), 487-491.

Cattarin, J. A., \& Thompson, J. K. (1994). A three-year longitudinal study of body image, eating disturbance and general psychological functioning in adolescent females. Eating Disorders: Journal of Treatment and Prevention, 2, 114-125. http://dx.doi.org/10.1080/10640269408249107

Centers for Disease Control and Prevention. (2014). Healthy Weight - it's not a diet, it's a lifestyle!. Available at: http://www.cdc.gov/healthyweight/index.html

Centers for Disease Control and Prevention. (2015). Can eating fruits and vegetables help people to manage their weight?. Available at: http://www.cdc.gov/nccdphp/dnpa/nutrition/pdf/rtp_practitioner_10_07.pdf

Cespedes, A. (2014). The pros and cons of fad diet. Available at: http://www.livestrong.com/article/366562-the-pros-cons-of-fad-diets/

Change4Life (2015). 5 A DAY- tips for getting five portions of fruit and veg each day. Available at: http://www.nhs.uk/Change4Life/Pages/five-a-day.aspx

Clifton, P., Noakes, M., Foster, P., \& Keogh, J. B. (2004). Do ketogenic diets for weight loss lower cardiovascular risk?. International Journal of Obesity, 28, S26.

Denke, M. (2001). Metabolic effects of high-protein, low-carbohydrate diets. American Journal of Cardiology, 88, 59-61. http://dx.doi.org/10.1016/S0002-9149(01)01586-7

Diabetes.co.uk. (2011). Dukan Diet. Available at: http://www.diabetes.co.uk/diet/dukan-diet.html

Dietz, W. H., \& Hartung, R. (1985). Changes in height velocity of obese preadolescents during weight reduction. American Journal of Diseases of Children, 139, 705-707.

Education.com. (2014). How do magazines affect body image. Available at: http://www.education.com/reference/article/how-magazines-affect-body-image/

Eisenstein, J. I., Roberts, S. B., Dallal, G., \& Saltzman, E. (2002). High-protein weight-loss diets: are they safe and do they work? A review of the experimental and epidemiologic data. Nutrition Reviews, 60(7 Pt1), 189-200. http://dx.doi.org/10.1301/00296640260184264

Epstein, L. H., Gordy, C. C., Raynor, H. A., Beddome, M., Kilanowski, C. K., \& Paluch, R. (2001). Increasing Fruit and Vegetable intake and Decreasing Fat and Sugar Intake in Families at Risk for Childhood Obesity. Obesity Research, 9(3), 171-178. http://dx.doi.org/10.1038/oby.2001.18

Field, A. E. (2000). Media influence in self-image: The real fashion emergency. Healthy Weight Journal, 11, 88-95.

Field, A. E., Austin, S. B., Taylor, C. B., Malspeis. S., Rosner, B., Rockett, H. R., ... Colditz, G. A. (2003). Relation between dieting and weight change among preadolescents and adolescents. Pediatrics, 112, 900-906.

Fisher, K. (2011). Uncover the pros and cons of fad dieting.

Available at: http://www.insidershealth.com/article/uncover_the_pros_and_cons_of_fad_dieting/3491

Fitness. (2014). Uncover the pros and cons of fad dieting.

Available at: http://www.fitness.com/articles/242/uncover_the_pros_and_cons_of_fad_dieting.php

Food and Nutrition Board, Institute of Medicine. (2005). Dietary Reference Intakes for Energy, Carbohydrate, Fiber, Fat, Fatty Acids, Cholesterol, Protein and Amino Acids. The National Academies Press. Available at: http://www.nap.edu/catalog/10490/dietary-reference-intakes-for-energy-carbohydrate-fiber-fat-fatty-acids-c holesterol-protein-and-amino-acids-macronutrients 
Food Standards Agency. (2010). Your guide to the eatwell plate-helping you eat a healthier diet. Available at: http://collections.europarchive.org/tna/20100927130941/http://food.gov.uk/multimedia/pdfs/publication/eat wellplateguide0310.pdf

Foster, G. D., Wyatt, H. R., Hill, J. O., McGuckin, B. G., Brill C., Mohammed, B. S., ... Klein S. (2003). A randomized trial of a low-carbohydrate diet for obesity. The New England Journal of Medicine, 348(21), 2082-2090. http://dx.doi.org/10.1056/NEJMoa022207

Foxcroft, L. (2011). Calories \& Corsets: A History of Dieting Over 2,000 Years (1st ed). London: Profile Books.

Freeman, J. M., Kossoff, E. H., \& Hartman, A. L. (2007). The Ketogenic Diet: One Decade Later. Padiatrics, 119, 535-543. http://dx.doi.org/10.1542/peds.2006-2447

Gardner, C. D., Kiazand, A., Alhassan, S., Kim, S., Stafford, R. S., Balise, R. R., ... King, A. C. (2007). Comparison of the Atkins, Zone, Ornish, and LEARN diets for change in weight and related risk factors among overweight premenopausal women: the A TO Z Weight Loss Study: a randomized trial. JAMA, 297(9), 969-977. http://dx.doi.org/10.1001/jama.297.9.969

Geissler, C. A., \& Powers, H. J. (2005). Human Nutrition (11th ed). Philadelphia: Elsevier.

Giovannucci, E., Rimm, E. B., Stampfer. M. J., Colditz. G. A., Ascherio, A., \& Willett, W. C. (1994). Intake of fat, meat, and fibre in relation to risk of colon cancer in men. Cancer Research, 54, 2390-2397.

Harris, J. L., Bargh, J. A., \& Brownell, K. D. (2009). Priming effects of television food advertising on eating behavior. Health Psychology, 28(4), 404-413. http://dx.doi.org/10.1037/a0014399

He, K., Hu, F. B., Colditz, G. A., Manson, J. E., Willett, W. C., \& Liu, S. (2004). Changes in intake of fruits and vegetables in relation to risk of obesity and weight gain among middle-aged women. International Journal of Obesity, 28, 1569-1574. http://dx.doi.org/10.1038/sj.ijo.0802795

Health and Social Care Information Centre. (2013). Statistics on obesity, physical activity and diet. Available at: http://www.hscic.gov.uk/catalogue/PUB10364

Health Research Funding. (2014). Pros and Cons of Fad Diets. Available at: http://healthresearchfunding.org/pros-cons-fad-diets/

Howarth, C., Saltzman, E., \& Roberts, B. (2001). Dietary Fiber and Weight Regulation, Nutrition Reviews, 59(5), 129-139. http://dx.doi.org/10.1111/j.1753-4887.2001.tb07001.x

Hughes, K. (2012). Calories \& Corsets: A History of Dieting Over 2,000 Years by Louise Foxcroft - review. The Guardian.

Available at: http://www.theguardian.com/books/2012/jan/13/calories-and-corsets-louise-foxcroft-review

Human Diseases and Conditions. (2014). Eating Disorders.

Available at: http://www.humanillnesses.com/original/E-Ga/Eating-Disorders.html\#ixzz3FZz0vdzs

Jebb, S., \& Goldberg, G. (1998). Efficacy of very low-energy diets and meal replacements in the treatment of obesity. Journal of Human Nutrition and Dietetics, 11(3), 219-226. http://dx.doi.org/10.1046/j.1365-277X.1998.00101.x

Ipatenco, S. (2014). The disadvantages of the Grapefruit diet. Available at: http://www.livestrong.com/article/427630-the-disadvantages-of-the-grapefruit-diet

Kreipe, R. E., Strauss J., Hodgman, C. H., \& Ryan R. M. (1989). Menstrual cycle abnormalities and subclinical eating disorders: A preliminary report. Psychosomatic Medicine; 51, 81-86.

Lang, T., \& Rayner, G. (2007). Overcoming policy cacophony on obesity: an ecological public health framework for policymakers. Obesity Reviews, 8, 165-181. http://dx.doi.org/10.1111/j.1467-789X.2007.00338.x

Lanza, E., Schatzkin, A., Daston, C., Corle, D., Freedman, L., Ballard-Barbash, R., ... the PPT Study Group. (2001). Implementation of a 4-y, high-fiber, high-fruit-and-vegetable, low-fat dietary intervention: results of dietary changes in the Polyp Prevention Trial. American Society for Clinical Nutrition, 74(3), 387-401.

Mahon K. L., \& Escott-Stump, S. (1996). Krause's Food, Nutrition, and Diet Therapy (9th ed). Philadelphia: W.B. Saunders Company.

Martin, A., Cherubini, A., Andres-Lacueva, C., Paniagua, M., \& Joseph, J. (2002). Effects of fruits and vegetables on levels of vitamins $\mathrm{E}$ and $\mathrm{C}$ in the brain and their association with cognitive performance. The Journal of Nutrition, Health and Aging, 6(6), 392-404. 
McClernon, F. J., Yancy, W. S., Eberstein, J. A., Atkins, R. C., \& Westman, E. C. (2007). The Effects of a Low-Carbohydrate Ketogenic Diet and a Low-Fat Diet on Mood, Hunger, and Other Self-Reported Symptoms. Obesity, 15(1), 182-187. http://dx.doi.org/10.1038/oby.2007.516

McNight, C. (2013). Health Risks of Yo-Yo Dieting. Available at: http://www.livestrong.com/article/353915-health-risks-of-yoyo-dieting

Mind, Exercise, Nutrition... Do it!. (2015). What we do. Available at: http://www.mendcentral.org/aboutus/whatwedo

Medicines and Healthcare products Regulatory Agency. (2014). Medicines and Healthcare products Regulatory Agency. Available at: http://www.mhra.gov.uk/index.htm\#page=DynamicListMedicines

Mirror Mirror Eating Disorders. (2014). Society and Eating Disorders. Available at: http://www.mirror-mirror.org/society.htm

National Health Services. (2013). Latest obesity stats for England are alarming - Health News - NHS Choices. Available at: http://www.nhs.uk/news/2013/02February/Pages/Latest-obesity-stats-for-England-are-alarming-reading.asp $\mathrm{x}$

National Health Services. (2014a). Obesity-Causes. Available at: http://www.nhs.uk/Conditions/Obesity/Pages/Causes.aspx

National Health Services. (2014b). Very low calorie diets. Available at: http://www.nhs.uk/Livewell/loseweight/Pages/very-low-calorie-diets.aspx

NHS Choices. (2014). Top diets review for 2014 - Live Well - NHS Choices. Available at: http://www.nhs.uk/Livewell/loseweight/Pages/top-10-most-popular-diets-review.aspx

National Institutes of Health. (1998). Clinical Guidelines On the Identification, Evaluation, and Treatment of Overweight and Obesity in Adults. Available at: http://www.ncbi.nlm.nih.gov/books/NBK2003/pdf/TOC.pdf

New, S. A., Robins, S. P., Campbell, M. K., Martin, J. C., Garton, M. J., Bolton-Smith, C., ... Reid, D. M. (2000). Dietary influences on bone mass and bone metabolism: further evidence of a positive link between fruit and vegetable consumption and bone health. American Journal of Clinical Nutrition, 71, 142-151.

Pereira, M. A., \& Ludwig, D. S. (2001). Dietary fiber and body-weight regulation: Observations and mechanisms, Pediatric Clinics of North America, 48(4), 969-980. http://dx.doi.org/10.1016/S0031-3955(05)70351-5

Polivy, J. (1996). Psychological consequences of food restriction, Journal of the American Dietetic Association, 96(6), 589-592. http://dx.doi.org/10.1016/S0002-8223(96)00161-7

Pritikin, N. (1981). The pritikin permanent weight loss manual. New York, NY: Grosset and Dunlap.

Reddy, S. T., Wang, C. Y., Sakhaee, K., Brinkley, L., \& Pack, C. Y. C. (2002). Effect of low-carbohydrate high-protein diets on acid-base balance, stone-forming propensity, and calcium metabolism. American Journal of Kidney Diseases, 40(2), 265-274. http://dx.doi.org/10.1053/ajkd.2002.34504

Refsum, H., Ueland, P. M., Nygard, O. \& Vollset, S. E. (1998). Homocystein and cardiovascular disease. Annual Review of Medicine, 49, 31-62. http://dx.doi.org/10.1146/annurev.med.49.1.31

Riccardi, G., Giacco, R., \& Rivellese, A. A. (2004). Dietary fat, insulin sensitivity and the metabolic syndrome. Clinical Nutrition, 23(4), 447-456. http://dx.doi.org/10.1016/j.clnu.2004.02.006

Rotchford, L. (2013). Diets through history: The good, the bad and the scary. CNN. Available at: http://edition.cnn.com/2013/02/08/health/diets-through-history

Scientific Advisory Committee on Nutrition. (2015). Carbohydrates and Health. London: TSO.

Sears, B., \& Lawren, B. (1995). The Zone-a dietary road map. New York, NY: Harper Collins.

Shulman, G. I. (2000). Cellular mechanisms of insulin resistance. Journal of Clinical Investigation, 106(2), 171-176. http://dx.doi.org/10.1172/JCI10583

Stern, D. (2015). The disadvantages of Slim Fast. Available at: http://www.livestrong.com/article/67235-disadvantages-slim-fast/

Stice, E., Cameron, R. P., Killen, J. D., Hayward, C., \& Taylor, C. B. (1999). Naturalistic weight-reduction efforts prospectively predict growth in relative weight and onset of obesity among female adolescents. Journal of Consulting \& Clinical Psychology, 67, 967-974. http://dx.doi.org/10.1037/0022-006X.67.6.967 
Strecher, V. J., Seijts, G. H., Kok, G. J., Latham, G. P., Glasgow, R., DeVellis, B., ... Bulger, D. W. (1995). Goal setting as a strategy for health behavior change. Health Education \& Behavior, 22, 190-200. http://dx.doi.org/10.1177/109019819502200207

Swinburn, B. A., Caterson, I., Seidell, J. C., \& James, W. P. T. (2004). Diet, nutrition and the prevention of excess weight gain and obesity. Public Health Nutrition, 7(1A), 123-146. http://dx.doi.org/10.1079/PHN2003585

Thomas, S. L., Hyde, J., Karunaratne, A., Kausman, R., \& Komesaroff, P. A. (2008). They all work...when you stick to them: A qualitative investigation of dieting, weight loss, and physical exercise, in obese individuals. Nutrition Journal, 7(34), 1-7. http://dx.doi.org/10.1186/1475-2891-7-34

Threapleton, D. E., Greenwood, D. C., Evans, C. E. L., Cleghorn, C. L., Nykjaer, C., Woodhead, C., ... Burley, V. J. (2013). Dietary fibre intake and risk of cardiovascular disease: systematic review and meta-analysis. $B M J$, 347, f6879. http://dx.doi.org/10.1136/bmj.f6879

Tohill, B. C. (2005). Dietary intake of fruits and vegetables and management of body weight. Available at: http://www.who.int/dietphysicalactivity/publications/f\%26v_weight_management.pdf

Truby, H., Baic, S., deLooy, A., Fox, K. R., Livingstone, M. B. E., Logan, C. M., ... Millward, D. J. (2006). Randomised control trial of four commercial weight loss programmes in the UK: initial findings from the BBC “diet trials". BMJ, 332(7555), 1309-1314. http://dx.doi.org/10.1136/bmj.38833.411204.80

Van den Berg, P., Neumark-Sztainer, D. R., Hannan, P. J., \& Haines, J. (2007). Is dieting advice from magazines helpful or harmful? Five-year associations with weight-control behaviors and psychological outcomes in adolescents. Pediatrics, 119(1), e30-e37. http://dx.doi.org/10.1542/peds.2006-0978

Visscher, T. L. S., \& Seidell, J. C. (2001). The Public Health Impact of Obesity. Annual Review of Public Health, 22, 355-375. http://dx.doi.org/10.1146/annurev.publhealth.22.1.355

Volek, J., Sharman, M., Gomez, A., Judelson, D., Rubin, M., Watson, G., ... Kraemer, W. (2004). Comparison of energy-restricted very low-carbohydrate and low-fat diets on weight loss and body composition in overweight men and women. Nutrition \& Metabolism (London), 1(1), 13. http://dx.doi.org/10.1186/1743-7075-1-13

Weight-control Information Network. (2014). Overweight and Obesity Statistics. Available at: http://win.niddk.nih.gov/statistics/index.htm

World Health Organisation. (2015). Obesity and overweight. Available at: http://www.who.int/mediacentre/factsheets/fs311/en/

World Health Organisation/Food \& Agriculture Organisation Expert Consultation. (2003). Joint Report: Diet, Nutrition and the Prevention of Chronic Diseases. WHO Technical Report Series, 916.

Westman, E. C., Feinman, R. D., Mavropoulos, J. C., Vernon, M. C., Volek, J. S., Wortman, J. A., ... Phinney, S. D. (2007). Low-carbohydrate nutrition and metabolism. The American journal of Clinical Nutrition, 86(2), 276-284.

Westman, E. C., Yancy, W. S., Edman, J. S., Tomlin, K. F. \& Perkins, C. P. (2002). Effect of 6-Month Adherence to a Very Low Carbohydrate Diet Program. The American Journal of Medicine, 113, 30-36. http://dx.doi.org/10.1016/S0002-9343(02)01129-4

Wood, R. J., Volek, J. S., Liu, Y., Shachter, N. S., Contois, J. H., \& Fernandez, M. L. (2006). Carbohydrate Restriction Alters Lipoprotein Metabolism by Modifying VLDL, LDL, and HDL Subfraction Distribution and Size in Overweight Men. The Journal of Nutrition, 136, 384-389.

Xu, H., Huang, X., Riserus, U., Krishnamurthy, V. M., Cederholm, T., Arnlov, J., ... Carrero, J. J. (2014). Dietary Fiber, Kidney Function, Inflammation, and Mortality Risk. Clinical Journal of the Americal Society of Nephrology, 9(12), 2104-2110. http://dx.doi.org/10.2215/CJN.02260314

\section{Copyrights}

Copyright for this article is retained by the author(s), with first publication rights granted to the journal.

This is an open-access article distributed under the terms and conditions of the Creative Commons Attribution license (http://creativecommons.org/licenses/by/4.0/). 